\title{
Selectivity of Post-emergence Herbicides for the Chickpea
}

\author{
Lucas da Silva Araújo ${ }^{1}$, Luís Gustavo Barroso Silva ${ }^{2}$, Mateus de Souza Valente ${ }^{2}$, \\ Anderson Rodrigo da Silva ${ }^{2}$, Paulo César Ribeiro da Cunha ${ }^{2} \&$ Warley Marcos Nascimento ${ }^{3}$ \\ ${ }^{1}$ School of Agronomy, University of Goiás, Ipameri, GO, Brazil \\ ${ }^{2}$ School of Agronomy, Institute Federal Goiano, Urutaí, GO, Brazil \\ ${ }^{3}$ Embrapa Vegetable, Brasília, DF, Brazil
}

Correspondence: Lucas da Silva Araújo, Department Vegetable Production, University of Goiás, Ipameri, GO, Brazil. E-mail: lucasilva_31@hotmail.com

Received: July 21, 2019

doi:10.5539/jas.v11n18p179
Accepted: September 24, $2019 \quad$ Online Published: November 15, 2019

URL: https://doi.org/10.5539/jas.v11n18p179

\begin{abstract}
Few herbicide options are available for controlling post-emergence weeds in the chickpea. The aim of this work therefore, was to study the selectivity of herbicides applied post-emergence for the chickpea 'BRS Aleppo'. Two experiments were carried out, one in the greenhouse and the other in the field (winter-spring crop). A completely randomised experimental design was used for the screening experiment (greenhouse), with 15 treatments and four replications. Fourteen treatments with herbicides $\left(\mathrm{g}\right.$ a.i. ha $\left.{ }^{-1}\right)$ were evaluated: bentazon (360 and 720), chlorimuron (10 and 20), clethodim (54 and 108), fluazifop (94 and 188), fomesafen (125 and 250), haloxyfop (30 and 60) and lactofen (90 and 180), in addition to the control with no application. From this experiment, herbicides that did not impair growth in the chickpea were selected for the field experiment based on plant height and shoot dry matter. During the field stage, a randomised block design was used, with 11 treatments and three replications. Ten treatments including the herbicides clethodim, fluazifop, fomesafen, haloxyfop and lactofen were evaluated in two rates, in addition to the control with no application. Based on the results of the two experiments, it was concluded that the ACCase inhibitors (clethodim, fluazifop and haloxyfop) caused no lesions or damage to the chickpea, while the latifolicides (fomesafen and lactofen) caused visual lesions which did not result in significant loss in yield. Bentazon (360 and $720 \mathrm{~g}$ a.i. ha $\left.{ }^{-1}\right)$ and chlorimuron-ethyl $\left(10\right.$ and 20 a.i. $\left.\mathrm{g} \mathrm{ha}^{-1}\right)$ were not selective, causing severe damage to the chickpea plants.
\end{abstract}

Keywords: Cicer arietinum L., chemical control, tolerance, weeds

\section{Introduction}

The chickpea (Cicer arietinum L.) is one of the world's leading grain legumes for human consumption and a major source of protein, fibre, vitamins, carbohydrates, minerals, unsaturated fatty acids and $\beta$-carotene (Jukanti et al., 2012). In 2017, 14.8 million tons were harvested on 14.6 million hectares around the world (FAO, 2019).

However, the low yield of the chickpea worldwide, of approximately $1014 \mathrm{~kg} \mathrm{ha}^{-1}$, is due in part to the problems faced with weeds, which is considered to be one of the most limiting factors in crop production (Solh and Pala, 1990). When present in areas of chickpea cultivation, weeds cause losses in production of from 25 to $97 \%$ (Al-Thahabi et al., 1994; Mohammadi et al., 2005; Paolini et al., 2006; Tepe et al., 2011). In Brazil, losses in chickpea yield due to weed interference have been estimated at $70 \%$, on average, irrespective of nitrogen fertiliser management (Amaral et al., 2018).

Weeds can therefore make cultivation of the chickpea economically inviable. The chickpea is an annual legume, with slow initial growth, open canopy architecture and small plants, and is thus highly susceptible to weed interference (Knights, 1991). In the case of poor crop management, greater attention should be paid to weed control to avoid a loss in yield.

Among the methods of control, the use of herbicides may be an alternative for controlling weeds in the chickpea, because, in addition to being more effective, it is faster and cheaper (Oliveira et al., 2011). However, in order to guarantee the success of chemical control, it is important to consider the selectivity of the herbicides for the crop in question; these should provide adequate weed control and, at the same time, not harm the crop of commercial interest (Oliveira Jr. \& Inoue, 2011). 
To date in Brazil, there are no registered herbicides for weed control in the chickpea (Agrofit, 2019; Rodrigues \& Almeida, 2018). In the United States there is a shortage of registered herbicides for post-emergence broadleaf control in the chickpea (Boydston et al., 2017). In Canada, metribuzin is the only registered herbicide for post-emergence broadleaf control in the chickpea (Saskatchewan Ministry of Agriculture, 2019). Globally therefore, post-emergence herbicides in chickpea cultivation are limited, especially those whose spectrum includes the control of broadleaf weeds.

Earlier research has shown the potential of graminicides (fluazifop, fenoxaprop and quizalofop) for controlling weeds of the Poaceae family with no adverse effect on the chickpea (Plew et al., 1994; Malik et al., 2001; Khan et al., 2018; Nath et al., 2018); of fomesafen and acifluorfen for the control of broadleaf weeds, even when causing visual lesions at the start of chickpea development (Malik et al., 2001; Boydston et al., 2017; Nath et al., 2018); while the potential of the herbicides imazethapyr, imazamox and metribuzin depends strongly on the correct choice of genotype, a poorly managed trait can compromise yield in areas of chickpea cultivation (Tar'an et al., 2010; Tar'an et al., 2013; Jain \& Tar'an, 2013; Gaur et al., 2013; Jefferies et al., 2016).

In Brazil, there is still a lack of information on the selectivity of herbicides in the chickpea. Based on botanical nearness, the hypothesis of the present study was that herbicides commonly used in other legumes, such as the common bean (Phaseolus vulgaris L.) and soybean (Glycine max L.), may be selective for the chickpea. As such, the aim was to study selectivity for the chickpea in post-emergence herbicides.

\section{Methods}

Two experiments were carried out, one in the greenhouse of the Plant Production Department in 2015, and the other in the field (winter-spring crop) in 2016, both at the Goiano Federal Institute, in Urutaí, in the state of Goiás, Brazil.

\subsection{Greenhouse Experiment}

In the greenhouse, the experimental design was completely randomised, with four replications. Initially, 14 treatments with herbicides (a.i. ha ${ }^{-1}$ ) were tested: 360 and $720 \mathrm{~g}$ bentazon, 10 and $20 \mathrm{~g}$ chlorimuron, 54 and 108 g clethodim, 94 and $188 \mathrm{~g}$ fluazifop, 125 and $250 \mathrm{~g}$ fomesafen, 30 and $60 \mathrm{~g}$ haloxyfop, and 90 and $180 \mathrm{~g}$ lactofen, in addition to the control with no product. Adjuvant $\left(0.5 \% \mathrm{v} \mathrm{v}^{-1}\right.$ of mineral oil) was added to the solution as per the manufacturer of each of the commercial products.

Each experimental unit consisted of a plastic pot with a capacity of $5.0 \mathrm{dm}^{3}$. Three plants of the chickpea 'BRS Aleppo' were maintained per vessel, which was filled only with soil belonging to the Class of Dystrophic Red Latosols removed from the 0.0 to 0.20 m layer, with a sandy loam texture (52\% sand, $37 \%$ clay and $11 \%$ silt), a $\mathrm{pH}$ of 5.6, $4.9 \mathrm{~g} \mathrm{dm}^{-3}$ organic matter and base saturation of $54 \%$. To supply water to the plants, each pot was placed in a larger-diameter vessel with no holes. Soil moisture was controlled periodically, with the water in the vessels being replaced whenever necessary.

The herbicides were applied to the chickpea when the plants had from 8 to 10 true leaves. The applications were made using an ADIA 110.015 sprayer, with a constant pressure of $2.4 \mathrm{kgf} \mathrm{cm}^{-2}$ maintained by $\mathrm{CO}_{2}$, equipped with a spray bar with four Magno flat-jet nozzles spaced $0.50 \mathrm{~m}$ apart, giving an application volume of $200 \mathrm{~L}$ $\mathrm{ha}^{-1}$. At the time of application, a relative humidity of $51.2 \%$, air temperature of $27.2^{\circ} \mathrm{C}$ and a wind speed of up to $2.6 \mathrm{~km} \mathrm{~h}^{-1}$ were recorded. Fifty-six days after application (DAA) of the herbicides, plant height was determined, measured from the base of the plant to the insertion of the last leaf on the main stem; dry matter was determined by collecting the complete aerial part of the plant. The plant material was dried in an oven at $65^{\circ} \mathrm{C}$ to constant weight, when the weight was determined. Herbicides that did not adversely affect plant growth, verified from the height and dry matter of the plants, were selected for use in the field.

\subsection{Field Experiment}

The field experiment was set up at $17^{\circ} 28^{\prime} 41^{\prime \prime} \mathrm{S}$ and $48^{\circ} 11^{\prime} 35^{\prime \prime} \mathrm{W}$ at a mean altitude of 800 metres. According to the Köppen classification, the climate is type Aw, humid tropical with dry winters (Alvarez et al., 2014). During the experiment, the temperature ranged from 15.6 to $34.1{ }^{\circ} \mathrm{C}$. The experimental area was irrigated via central pivot. When necessary, a 10-mm irrigation depth was applied.

The soil of the experimental area also belongs to the class of dystrophic Red Latosols, with a clayey texture ( $49 \%$ sand, $37 \%$ clay and $14 \%$ silt). The initial values for the chemical attributes of the soil in the 0.0 to $0.20 \mathrm{~m}$ layer were: a $\mathrm{pH}$ of $5.1,1.1 \mathrm{cmol}_{\mathrm{c}} \mathrm{dm}^{-3} \mathrm{H}^{+}+\mathrm{Al}^{+}, 2.5 \mathrm{~g} \mathrm{dm}^{-3}$ organic matter, $3.4 \mathrm{mg} \mathrm{dm} \mathrm{d}^{-3} \mathrm{P}, 110 \mathrm{mg} \mathrm{dm}^{-3} \mathrm{~K}^{+}, 1.9$ $\mathrm{cmol}_{\mathrm{c}} \mathrm{dm}^{-3} \mathrm{Ca}^{2+}, 0.8 \mathrm{cmol}_{\mathrm{c}} \mathrm{dm}^{-3} \mathrm{Mg}^{2+}$ and a base saturation of $53 \%$. 
The experimental area was prepared conventionally by harrowing to a depth of $\pm 0.25 \mathrm{~m}$, followed by two passes of the harrow to break up the surface soil. Sixty kg ha ${ }^{-1} \mathrm{~K}_{2} \mathrm{O}$ was then broadcast in the form of potassium chloride. Planting furrows were opened using a six-row, mechanically drawn bar plough. Sowing was by hand, at a spacing of $0.50 \mathrm{~m}$ between rows, with 22 seeds distributed per metre. Fertiliser was manually applied when sowing at a rate of $500 \mathrm{~kg} \mathrm{ha}^{-1}$ single superphosphate $\left(18 \% \mathrm{P}_{2} \mathrm{O}_{5}, 16 \% \mathrm{Ca}^{2+}\right.$ and $\left.8 \% \mathrm{~S}\right)$. Twenty-four days after chickpea emergence, $70 \mathrm{~kg} \mathrm{ha}^{-1} \mathrm{~N}$ was applied as cover in the form of urea.

The experimental design was of randomised blocks with three replications. Ten treatments with herbicides (a.i. $\mathrm{ha}^{-1}$ ) were tested: 54 and $108 \mathrm{~g}$ clethodim, 94 and $188 \mathrm{~g}$ fluazifop, 125 and $250 \mathrm{~g}$ fomesafen, 30 and $60 \mathrm{~g}$ haloxyfop and 90 and $180 \mathrm{~g}$ lactofen, in addition to the control with no application. Adjuvant $\left(0.5 \% \mathrm{v} \mathrm{v}^{-1}\right.$ of mineral oil) was added to the solution as per the manufacturer of each of the commercial products. Each experimental plot was $2.0 \mathrm{~m}$ in width $\times 4.0 \mathrm{~m}$ in length, giving a total area of $8.0 \mathrm{~m}^{2}$ and a working area of 1.5 $\mathrm{m}^{2}$.

The herbicides were applied when the chickpea plants had between 8 and 10 leaves, similar to in the greenhouse. The same application technology described for the greenhouse experiment was used. At the time of application, a relative humidity of $32.8 \%$, air temperature of $29.9^{\circ} \mathrm{C}$, and a wind speed of up to $3.6 \mathrm{~km} \mathrm{~h}^{-1}$ were recorded.

All the experimental plots were kept free of weeds until the chickpea was harvested, with the manual elimination of any weeds escaping chemical control, and the removal by hand of all the weeds in the treatment with no commercial product.

Possible visual damage in the chickpea plants was evaluated at 14, 28 and 42 days after application (DAA) of the herbicides, using a scale of 0 to $100 \%$, where zero means no visual damage and 100 means the death of the plant (Velini et al., 1995). The chickpea was harvested 120 days after sowing.

The selectivity of the herbicides was evaluated using the following agronomic variables: days to flowering, when $50 \%$ of the plants in the working area of the plot had at least one open flower, considering the number of days from emergence to flowering; shoot dry matter, collected during full flowering (two samples of one metre from each row within the working area of each plot); grain yield, the weight of all of the grain from the working area of the experimental plots, with the values estimated in $\mathrm{kg} \mathrm{ha}^{-1}$; number of pods per plant, a count of all the pods from ten plants in the working area of each plot; and the 100-grain weight. The values for grain yield and weight were corrected for $13 \%$ moisture.

\subsection{Data Analysis}

The data were submitted to univariate analysis of variance (F-test). The residuals were tested for normality by the Shapiro-Wilk test, and homoscedasticity by Bartlett's test. The mean values of the treatments were compared by LSD (Least Significant Difference, $\alpha=0.05$ ). Each treatment with herbicide was individually compared to the control using Dunnett's test $(\alpha=0.05)$. The statistical analysis was carried out using the R v3.0.3 software (R Core Team, 2017).

\section{Results}

In the greenhouse experiment, there was a significant effect between the herbicides $(p<0.05)$ on chickpea growth (Table 1). The treatments that included the ACCase inhibitors (54 and $108 \mathrm{~g}$ a.i. ha ${ }^{-1}$ clethodim, 94 and $188 \mathrm{~g}$ a.i. ha ${ }^{-1}$ fluazifop, and 30 and $60 \mathrm{~g}$ a.i. ha ${ }^{-1}$ haloxyfop) and the latifolicides (125 and $250 \mathrm{~g}$ a.i. ha ${ }^{-1}$ fomesafen, and 90 and $180 \mathrm{~g}$ a.i. ha ${ }^{-1}$ lactofen) had no effect on plant height or shoot dry matter, different to the herbicides bentazon and chlorimuron, that negatively affected chickpea growth. Due to the toxic effect on the plants, bentazon reduced plant height and shoot dry matter by, on average, $52 \%$ and $83 \%$ respectively, whereas chlorimuron gave a respective mean reduction of $68 \%$ and $96 \%$. 
Table 1. Screening to evaluate the potential of herbicides applied in post-emergence for chickpea cv. BRS Aleppo-greenhouse experiment

\begin{tabular}{llll}
\hline Treatment & Rate & Height & Dry matter \\
\hline Bentazon & g a.i. ha $\mathrm{h}^{-1}$ & $\mathrm{~cm}$ & $\mathrm{~g}$ \\
Bentazon & 360 & $20.9 \mathrm{~b}^{(-)}$ & $5.1 \mathrm{~b}^{(-)}$ \\
Chlorimuron & 720 & $13.5 \mathrm{c}^{(-)}$ & $1.0 \mathrm{bc}^{(-)}$ \\
Chlorimuron & 10 & $10.6 \mathrm{c}^{(-)}$ & $1.0 \mathrm{bc}^{(-)}$ \\
Clethodim & 20 & $12.0 \mathrm{c}^{(-)}$ & $0.6 \mathrm{c}^{(-)}$ \\
Clethodim & 54 & $34.1 \mathrm{a}$ & $17.9 \mathrm{a}$ \\
Fluazifop & 108 & $33.7 \mathrm{a}$ & $15.4 \mathrm{a}$ \\
Fluazifop & 94 & $35.9 \mathrm{a}$ & $16.4 \mathrm{a}$ \\
Fomesafen & 188 & $37.1 \mathrm{a}$ & $16.4 \mathrm{a}$ \\
Fomesafen & 125 & $38.0 \mathrm{a}$ & $16.8 \mathrm{a}$ \\
Haloxyfop & 250 & $37.2 \mathrm{a}$ & $15.5 \mathrm{a}$ \\
Haloxyfop & 30 & $34.6 \mathrm{a}$ & $17.7 \mathrm{a}$ \\
Lactofen & 60 & $38.3 \mathrm{a}$ & $18.1 \mathrm{a}$ \\
Lactofen & 90 & $35.2 \mathrm{a}$ & $16.6 \mathrm{a}$ \\
Untreated & 180 & $35.0 \mathrm{a}$ & $14.0 \mathrm{a}$ \\
- & - & $35.5 \mathrm{a}$ & $17.4 \mathrm{a}$ \\
& F $(\mathrm{p}<0.05)$ & 0.000 & 0.000 \\
& LSD & 6.77 & 4.34 \\
& CV $(\%)$ & 8.44 & 12.89
\end{tabular}

Note. Means followed by the same letter in the column are not significantly different by the LSD test $(\mathrm{p}<0.05)$.

Means followed by (-) were lower than the control (without application of product), by the Dunnet test ( $\mathrm{p}<$ $0.05)$.

In the field experiment, the herbicides fomesafen (125 and $250 \mathrm{~g}$ a.i. ha $\left.{ }^{-1}\right)$ and lactofen $\left(90\right.$ and $180 \mathrm{~g}$ a.i. ha $\left.{ }^{-1}\right)$ caused visual damage to the plants but did not cause the death of the chickpea. At 14 DAA, the lesions were more pronounced, ranging from 16 to $41 \%$ (Table 1). On average, lactofen caused greater damage to the plants than did fomesafen. However, over time, at 28 and 42 DAA, the chickpea plants resumed satisfactory growth. On the other hand, the herbicides clethodim, fluazifop and haloxyfop caused no visual damage to the plants. The agronomic variables (days to flowering, dry matter, number of pods per plant, 100-grain weight and grain yield) were not altered by the application of the herbicides $(p \geq 0.05)$, and therefore did not differ from the control (Table 2). 
Table 2. Selectivity of herbicides applied in post-emergence for chickpea cv. BRS Aleppo-experiment in field conditions

\begin{tabular}{|c|c|c|c|c|c|c|c|c|c|}
\hline \multirow{2}{*}{ Treatment } & \multirow{2}{*}{$\begin{array}{l}\text { Rate } \\
(\text { g a.i. ha-1) }\end{array}$} & \multicolumn{3}{|c|}{ Crop injury (\%) } & \multirow{2}{*}{$\begin{array}{l}\text { Days for } \\
\text { flowering }\left(\mathrm{n}^{\circ}\right)\end{array}$} & \multirow{2}{*}{$\begin{array}{l}\text { Dry matter } \\
\left(\text { g plant }^{-1}\right)\end{array}$} & \multirow{2}{*}{$\begin{array}{l}\text { Pods } \\
\left(n^{\circ} \text { plant }^{-1}\right)\end{array}$} & \multirow{2}{*}{$\begin{array}{l}\text { 100-grain } \\
\text { weight }(\mathrm{g})\end{array}$} & \multirow{2}{*}{$\begin{array}{l}\text { Yield } \\
\left(\mathrm{kg} \mathrm{ha}^{-1}\right)\end{array}$} \\
\hline & & $14 \mathrm{DAA}$ & $28 \mathrm{DAA}$ & $42 \mathrm{DAA}$ & & & & & \\
\hline Clethodim & 54 & $0.0 \mathrm{a}$ & $0.0 \mathrm{a}$ & 0.0 & 42 & 13.50 & 31.7 & 30.2 & 3017 \\
\hline Clethodim & 108 & $0.0 \mathrm{a}$ & $0.0 \mathrm{a}$ & 0.0 & 42 & 13.03 & 27.3 & 30.4 & 3204 \\
\hline Fluazifop & 94 & $0.0 \mathrm{a}$ & $0.0 \mathrm{a}$ & 0.0 & 42 & 13.03 & 29.3 & 31.0 & 2959 \\
\hline Fluazifop & 188 & $0.0 \mathrm{a}$ & $0.0 \mathrm{a}$ & 0.0 & 42 & 12.20 & 30.7 & 31.3 & 2871 \\
\hline Fomesafen & 125 & $16.0 \mathrm{~b}^{(+)}$ & $2.66 \mathrm{~b}^{(+)}$ & 0.0 & 42 & 13.56 & 39.0 & 31.0 & 3295 \\
\hline Fomesafen & 250 & $19.7 \mathrm{a}^{(+)}$ & $4.66 \mathrm{~b}^{(+)}$ & 0.0 & 42 & 12.40 & 27.3 & 31.1 & 2560 \\
\hline Haloxyfop & 30 & $0.0 \mathrm{a}$ & $0.0 \mathrm{a}$ & 0.0 & 42 & 12.90 & 34.2 & 30.2 & 2898 \\
\hline Haloxyfop & 60 & $0.0 \mathrm{a}$ & $0.0 \mathrm{a}$ & 0.0 & 42 & 13.50 & 34.7 & 32.0 & 3010 \\
\hline Lactofen & 90 & $29.3 \mathrm{~d}^{(+)}$ & $12.00 \mathrm{c}^{(+)}$ & 0.0 & 42 & 10.66 & 28.9 & 30.8 & 3062 \\
\hline Lactofen & 180 & $41.3 \mathrm{e}^{(+)}$ & $17.33 \mathrm{~d}^{(+)}$ & 0.0 & 42 & 9.16 & 26.7 & 30.8 & 2488 \\
\hline \multirow[t]{4}{*}{ Untreated } & - & $0.0 \mathrm{a}$ & $0.0 \mathrm{a}$ & 0.0 & 42 & 15.26 & 36.7 & 31.4 & 2917 \\
\hline & $\mathrm{F}(\mathrm{p}<0.05)$ & 0.000 & 0.000 & - & - & 0.633 & 0.432 & 0.245 & 0.753 \\
\hline & LSD & 2.94 & 2.11 & - & - & 9.91 & 22.02 & 2.49 & 1635.89 \\
\hline & CV (\%) & 9.57 & 19.90 & - & - & 24.64 & 22.00 & 2.54 & 17.55 \\
\hline
\end{tabular}

Note. Means followed by the same letter in the column are not significantly different by the LSD test $(\mathrm{p}<0.05)$.

Means followed by $(+)$ were higher than the control (without application of product), by the Dunnet test $(\mathrm{p}<$ $0.05)$.

\section{Discussion}

The ACCase inhibitors (clethodim, fluazifop and haloxyfop), which only control species of family Poaceae, did not cause lesions in the chickpea plants; unlike the latifolicides (bentazon, chlorimuron, fomesafen and lactofen), which have a broader spectrum for the control of dicotyledonous species, and which caused lesions, especially chlorosis or necrosis.

In the greenhouse, the application of 360 and $720 \mathrm{~g}$ a.i. ha ${ }^{-1}$ bentazon caused severe lesions or death in the chickpea, and consequently affected growth, with plants of reduced size and less shoot dry matter at 56 DAA. Under field conditions, Tanveer et al. (2010) found 100\% mortality in the chickpea cultivar Bital-98 with the application of $720 \mathrm{~g}$ a.i. ha ${ }^{-1}$ bentazon, corroborating the present study. Bentazon (1000 and $\left.1500 \mathrm{~g} \mathrm{a}^{\mathrm{i} . \mathrm{ha}^{-1}}\right)$, applied post-emergence, also caused severe damage or death in the Kabuli chickpea, with a loss in yield of $90.3 \%$ and $86.1 \%$ respectively (Plew et al., 1994). A loss of $68 \%$ in the yield of the chickpea cultivar L-144 was also seen with the application of $1500 \mathrm{~g}$ a.i. ha ${ }^{-1}$ bentazon (Yadav et al., 1983). As such, the results confirm the high susceptibility of the chickpea to the herbicide, bentazon.

Severe damage to the chickpea was also found from the application of 10 and $20 \mathrm{~g}$ a.i. ha ${ }^{-1}$ chlorimuron, with a negative effect on plant height and dry matter. Severe phytotoxic action of chlorimuron $\left(3\right.$ and $\left.4 \mathrm{~g} \mathrm{ha}^{-1}\right)$ was recorded in the chickpea cultivar DCP 92-3 intercropped with mustard, resulting in a loss in yield of $90 \%$ and $92 \%$ respectively (Kumar et al., 2015).

The herbicides fomesafen (125 and $250 \mathrm{~g}$ a.i. ha ${ }^{-1}$ ) and lactofen ( 90 and $180 \mathrm{~g}$ a.i. ha $\mathrm{h}^{-1}$ ) caused necrotic lesions on the leaves of the chickpea, but the symptoms decreased over time. Due to plant recovery, height and shoot dry matter were not affected, thereby showing satisfactory growth. The ACCase inhibitors (clethodim, fluazifop and haloxyfop), caused no visual lesions and as such, the chickpea plants again showed satisfactory growth.

Based on the results obtained in the greenhouse experiment, the chickpea did not tolerate the post-emergent application of 360 and $720 \mathrm{~g}$ a.i. ha ${ }^{-1}$ bentazon, or 10 and $20 \mathrm{~g}$ a.i. ha ${ }^{-1}$ chlorimuron, unlike the application of the herbicides clethodim, fluazifop, fomesafen, haloxyfop and lactofen, which were selected for the field experiment as they did not affect the growth (height or dry matter) of the chickpea plants.

Corroborating the field data, the herbicides clethodim, fluazifop and haloxyfop, irrespective of the rate, caused no visual damage to the chickpea. These results are confirmed by the natural tolerance mechanism found in dicotyledonous crops, which is the presence of an ACCase (acetyl-CoA carboxylase), in its prokaryotic form insensitive to graminicides and therefore unaffected by the herbicides (Sasaki et al., 1995). 
In other studies, the chickpea proved to be tolerant to applications of clethodim (60 and $120 \mathrm{~g}$ a.i. $\left.\mathrm{ha}^{-1}\right)$ and haloxyfop (150 and $300 \mathrm{~g}$ a.i. ha ${ }^{-1}$ ), for the Kabuli (Plew et al., 1994), and fluazifop (50 and $75 \mathrm{~g}$ a.i. ha ${ }^{-1}$ ) for 'CM-72' (Malik et al., 2001); as well as other ACCase inhibitors, such as fenoxaprop, for 'Karak-I' (Khan et al., 2018), and clodinafop or quizalofop for 'JG 130' (Nath et al., 2018).

On the other hand, the herbicides fomesafen (125 and $250 \mathrm{~g}$ a.i. ha $\left.{ }^{-1}\right)$ and lactofen $\left(90\right.$ and $180 \mathrm{~g}$ a.i. ha $\left.{ }^{-1}\right)$ caused visual damage to the plants up to 28 DAA. These were no longer seen at 42 DAA as a result of plant recovery, possibly in response to non-translocation of the herbicides. The injury, characterised as whitish necrotic lesions, were restricted to the leaves that intercepted the spray jet, and new leaves, emitted after application, showed no visual damage.

Similar to the greenhouse data, visual damage was more marked as the rate of herbicide increased, with lactofen again causing the greatest visual damage. However, the chickpea grown in the field showed a greater capacity for recovery compared to under greenhouse conditions.

In fact, herbicides belonging to the diphenyl-ether chemical group, such as fomesafen and lactofen, show little selectivity when in direct contact with the leaves, but do not cause the death of the chickpea crop. Other studies have also demonstrated the potential of fomesafen for use in post-emergence spraying of the chickpea at a rate of $130 \mathrm{~g}$ a.i. ha ${ }^{-1}$ for 'CM-72' (Malik et al., 2001), and at $280 \mathrm{~g}$ a.i. ha ${ }^{-1}$ for 'Sierra' (Boydston et al., 2017). The same was seen for acifluorfen, sprayed post-emergence at rates of 500 and $420 \mathrm{~g}$ a.i. ha ${ }^{-1}$, which also showed selectivity for the Sierra and JG 130 cultivars respectively (Boydston et al., 2017; Nath et al., 2018).

There were no significant effects from the herbicides on the agronomic variables: days to flowering, shoot dry matter, number of pods per plant, 100-grain weight or grain yield. The ACCase inhibitors (clethodim, fluazifop and haloxyfop) cause no lesions or damage to the chickpea, while the latifolicides (fomesafen and lactofen) cause visual damage that does not result in a significant loss in yield.

Based on the greenhouse and field data, it was found that the chickpea did not tolerate the post-emergence application of bentazon or chlorimuron; whereas the herbicides clethodim, fluazifop, fomesafen, haloxyfop and lactofen can be used as future options for chemical control of weeds in commercial chickpea areas.

\section{Conclusion}

Clethodim (54 and $108 \mathrm{~g}$ a.i. ha ${ }^{-1}$ ), fluazifop (94 and $188 \mathrm{~g}$ a.i. $\mathrm{ha}^{-1}$ ), fomesafen (125 and $250 \mathrm{~g}$ a.i. ha ${ }^{-1}$ ), haloxyfop (30 and $60 \mathrm{~g}$ a.i. ha ${ }^{-1}$ ) and lactofen $\left(90\right.$ and $180 \mathrm{~g}$ a.i. $\mathrm{ha}^{-1}$ ) were selective when applied post-emergence in the BRS Aleppo cultivar. The herbicides bentazon (360 and $720 \mathrm{~g}$ a.i. ha ${ }^{-1}$ ) and chlorimuron (10 and $20 \mathrm{~g}$ a.i. ha ${ }^{-1}$ ) were not selective for the chickpea.

\section{Acknowledgements}

First author thanks the Foundation for Research Support of the State of Goiás, project number 20151026700 901 for granting the Master's scholarship.

The authors thank the Instituto Federal Goiano (Brazil) for the financial support.

\section{References}

Al-Thahabi, A. S., Yasin, I. Z., Abu-Irmaileh, B. E., Haddad, N. I., \& Saxena, M. C. (1994). Effect of weed removal on productivity of chickpea (Cicer arietinum L.) and lentil (Lens culinaris Med.) in a mediterranean environment. Journal Agronomy and Crop Science, 172, 333-341. https://doi.org/10.1111/ j.1439-037X.1994.tb00184.x

Alvares, C. A., Stape, J. L., Sentelhas, P. C., Gonçalves, J. L. M., \& Sparovek, G. (2014). Köppen's climate classification map for Brazil. Meteorologische Zeitschrift, 22, 711-728. https://doi.org/10.1127/0941-2948/ 2013/0507

Amaral, C. L., Pavan, G. B., Pereira, F. C. M., \& Alves, P. L. C. A. (2018). Periods of weed interference in chickpea grown under different doses of nitrogen fertilizer topdressing. Acta Scientiarum. Agronomy, 40, 1-10. http://dx.doi.org/10.4025/actasciagron.v40i1.35666

Boydston, R. A., Nelson, H., \& Chaves-Cordoba, B. (2017). Tolerance of chickpeas to postemergence broadleaf herbicides. Weed Technology, 32, 190-194. https://doi.org/10.1017/wet.2017.99

FAO (Food and Agriculture Organization of the United Nations). (2016). Data base Faostat. Retrieved March 15, 2019, from http://www.fao.org/faostat/en/\#data 
Gaur, P. M., Jukanti, A. K., Samineni, S., Chaturvedi, S. K., Singh, S., Tripathi, S., ... Gowda, C. L. L. (2013). Large genetic variability in chickpea for tolerance to herbicides imazethapyr and metribuzin. Agronomy, 3, 524-536. https://doi.org/10.3390/agronomy3030524

Jefferies, M. L., Willenborg, C. J., \& Tar'an, B. (2016). Response of conventional and imidazolinone-resistant chickpea (Cicer arietinum L.) cultivars to imazamox and/or imazethapyr applied post-emergence. Canadian Journal of Plant Science, 96, 48-58. https://doi.org/10.1139/cjps-2015-0144

Jukanti, A. K., Gaur, P. M., Gowda, C. L. L., \& Chibbar, R. N. (2012). Nutritional quality and health benefits of chickpea (Cicer arietinum L.): A review. British Journal of Nutrition, 108, 11-26. https://doi.org/10.1017/ S0007114512000797

Khan, I. A., Khan, R., Jan, A., \& Shah, S. M. A. (2018). Studies on tolerance of chickpea to some pre and post-emergence herbicides. Emirates Journal of Food and Agriculture, 30, 725-73. https://doi.org/10.9755/ ejfa.2018.v30.i9.1804

Knights, E. (1991). Chickpea. In R. S. Jessop \& R. L. Wright (Eds.), New Crops, Agronomy and Potential of Alternative Crop Species (pp. 27-38). Melbourne: Inkata Press.

Kumar, N., Hazra, K. K., Yadav, S. L., \& Singh, S. S. (2015). Weed management using post-emergence herbicides in chickpea (Cicer arietinum) + mustard (Brassica juncea) intercropping system. Indian Journal of Agricultural Sciences, 85, 1074-1079.

Malik, M. R., Haqqani, A. M., Rehman, H., Ozair, C. A., \& Malik, B. A. (2001). Economic efficacy of different pre and post-emergence herbicides to control weeds in chickpea (Cicer arietinum L.). Journal of Biological Sciences, 1, 372-377. https://doi.org/10.3923/jbs.2001.372.377

Mohammadi, G., Javanshir, A., Khooie, F. R., Mohammadi, S. A., \& Zehtab Salmasi, S. (2005). Critical period of weed interference in chickpea. Weed Research, 45, 57-63. https://doi.org/10.1111/j.1365-3180.2004. 00431.x

Nath, C. P., Dubey, R. P., Sharma, A. R., Hazra, K. K., Kumar, N., \& Singh, S. S. (2018). Evaluation of new generation post-emergence herbicides in chickpea (Cicer arietinum L.). National Academy Science Letters, 41, 1-5. https://doi.org/10.1007/s40009-017-0604-z

Oliveira Jr. R. S., \& Inoue, M. H. (2011). Seletividade de herbicidas para culturas e plantas daninhas. In R. S. Oliveira Jr., J. Constantin, \& M. H. Inoue (Eds.), Biologia e manejo de plantas daninhas (pp. 243-262). Curitiba: Omnipax.

Oliveira Jr., R. S. (2011). Introdução ao controle químico. In R. S. Oliveira Jr., J. Constantin, \& M. H. Inoue (Eds.), Biologia e manejo de plantas daninhas (pp. 125-140). Curitiba: Omnipax.

Paolini, R., Faustini, F., Saccardo, F., \& Crino, P. (2006). Competitive interactions between chickpea genotypes and weeds. Weed Research, 46, 335-344. https://doi.org/10.1111/j.1365-3180.2006.00513.x

Plew, J. N., Hill, G. D., \& Dastgheib, F. (1994). Weed control in chickpeas (Cicer arietinum). Proceedings Agronomy Society of New Zealand, 24, 117-124.

R Development Core Team. (2017). R: A language and environment for statistical computing. R Foundation for Statistical Computing. Retrieved February 15, 2019, from http://www.R-project.org

Rodrigues, B. N., \& Almeida, F. S. (2018). Guia de herbicidas (7th ed). Londrina: Editing authors.

Sasaki, Y., Konishi, T., \& Nagano, T. (1995). The compartmentation of acetyl-coenzyme A carboxylase in plants. Plant Physiology, 108, 445-449. https://doi.org/10.1104/pp.108.2.445

Solh, M. B., \& Pala, M. (1990). In: M. C. Saxena, J. I. Cubero, \& Wery, J. (Eds.). Weed control in chickpea. In: Present status and future prospects of chickpea crop production and improvement in the Mediterranean countries (pp. 93-99). Zaragoza: Ciheam.

Tanveer, A., Imran, S., Ayub, M., \& Yasin, M. (2010). Response of chickpea (Cicer arietinum) and Euphorbia dracunculoides to pre and post-emergence herbicides. Pakistan Journal of Weed Sciences Research, 16, 267-277.

Tar'an, B., Holm, F., \& Banniza, S. (2013). Response of chickpea cultivars to pre- and post-emergence herbicide applications. Canadian Journal of Plant Science, 93, 279-286. https://doi.org/10.4141/cjps2012-167 
Tepe, I., Erman, M., Yergin, R., \& Bükün, B. (2011). Critical period of weed control in chickpea under non-irrigated conditions. Turkish Journal of Agriculture and Forestry, 35, 525-534. https://doi.org/ 10.3906/tar-1007-956

Velini, D. E., Osipe, R., \& Gazziero, D. L. P. (1995). Procedimentos para instalação, avaliação e análise de experimentos com herbicidas. Londrina: SBCPD.

Yadav, S. K., Singh, S. P., \& Bhan, V. M. (1983). Weed control in chickpea. Tropical Pest Management, $29,297$. https://doi.org/10.1080/09670878309370819

\section{Copyrights}

Copyright for this article is retained by the author(s), with first publication rights granted to the journal.

This is an open-access article distributed under the terms and conditions of the Creative Commons Attribution license (http://creativecommons.org/licenses/by/4.0/). 